\title{
Kosraean Language
}

National Cancer Institute

\section{Source}

National Cancer Institute. Kosraean Language. NCI Thesaurus. Code C153985.

An Austroasiatic language spoken on the Kosrae and Caroline Islands of Micronesia, and Nauru. 